\title{
Nazal kavitenin nadir bir primer tümörü olarak leiyomiyosarkom
}

\section{Leiomyosarcoma as a rare primary tumor of nasal cavity}

Mustafa Şahin ${ }^{1} \quad$ Sercan Göde ${ }^{2} \quad$ Raşit Midilli $^{2}$

${ }^{1}$ Dışkapı Yıldırım Beyazıt Eğitim ve Araştırma Hastanesi, Kulak Burun Boğaz Kliniği, Ankara, Türkiye

${ }^{2}$ Ege Üniversitesi Tıp Fakültesi, Kulak Burun Boğaz Anabilim Dalı, İzmir, Türkiye

\section{Öz}

Düz kas hücrelerinden kaynaklanan, genelde endometrium ve gastrointestinal traktta saptanan leiyomiyosarkom, nadir görülen yumuşak doku tümörlerindendir. Burun ve paranazal kavitenin en sık görülen malignite tipi olan karsinomlara nazaran sarkomların insidansı bir hayli düşüktür ve bu bölgenin sarkomları arasında leiyomiyosarkoma az rastlanmaktadır. Bu tümörlerde genelde tercih edilen tedavi cerrahi rezeksiyondur. Bu yazıda nadir bir yerleşim yeri olarak alt konka posteriorundan kaynaklanmış ve endoskopik transnazal cerrahi rezeksiyon ile tedavi edilmiş bir nazal kavite leiyomiyosarkomu olgusu, literatür bilgileri eşliğinde sunulmaktır.

Anahtar Sözcükler: Nazal kavite, leiyomiyosarkom.

\begin{abstract}
Leimyosarcoma is a rare soft tissue tumor originating from smooth muscle cells and it is usually diagnosed in the endometrium and gastrointestinal tract. Compared with carcinomas which are the most common malignancies of the nose and the paranasal cavity, the incidence of sarcomas is quite low and leiomyosarcomas are rarely found among these sarcomas. Surgical excision is the usually preferred treatment choice for these tumors. In this paper, a case with nasal cavity leimyosarcoma originating from a rare location as the posterior part of lower concha and treated with endoscopic transnasal surgical excision is presented with the relevant literature.
\end{abstract}

Keywords: Nasal cavity, leiomyosarcoma.

\section{Giriş}

Tüm yumuşak doku sarkomlarının yaklaşık $7 \%$ sini leiyomisarkomlar (LMS), uterus ve gastrointestinal trakt gibi düz kas dokusundan zengin organlardan, nadiren ekstremiteler ve baş-boyun bölgesi gibi diğer vücut bölgelerinden kaynaklanmaktadırlar. Baş-boyun bölgesi LMS'larının, kan damarlarının tunika mediasından, sirkumvallat papillalardan, tükrük bezi miyoepitelyal hücrelerinden ya da pluripotent mezenkimal hücrelerden kaynaklandıkları düşünülmektedir (1). Bu tümör tipinin, sinonazal bölgedeki tümörler içindeki insidansı 1.5\%$2.1 \%$ ile bir hayli düşüktür. LMS tedavisindeki en etkili yöntemin cerrahi olduğu konusunda genel bir kanı bulunmaktadır, tedavi başarısındaki en önemli unsur ise tümörün boyutudur (2). Eskiden LMS tedavisindeki rolleri palyatif olan radyoterapi (RT) ve kemoterapinin (KT) ise yeni tedavi rejimlerinin tanımlanması ile cerrahi sonrası uygulanmaları giderek artmaktadır (3).

Yazışma Adresi: Mustafa ŞAHIN

Dışkapı Yıldırım Beyazıt Eğitim ve Araştırma Hastanesi, Kulak Burun Boğaz Kliniği, Ankara, Türkiye

Makalenin Geliş Tarihi: 11.08.2014

Kabul Tarihi: 17.09.2014
$\mathrm{Bu}$ yazıda burun kanaması ve burun tıkanıklığı şikayetleri ile başvuran, muayenesinde saptanan nazal kitlenin LMS olarak belirlenmesi üzerine cerrahi rezeksiyon ve sonrasında RT ile tedavi edilen, 3 yılı aşkın izleminde nüks saptanmayan 57 yaşındaki kadın hasta sunulmaktadır.

\section{Olgu Sunumu}

57 yaşında kadın hasta, bir yıldır ara ara olan burun kanaması ve giderek artan tek taraflı burun tıkanıklığı şikayetleri ile başvurdu. Yapılan fizik muayenesinde endoskopik bakı ile görülebilen sol nazal kavite posteriorunda koanaya geçişi tama yakın engelleyen ağrısız kitle saptandı. Diğer kulak burun boğaz muayeneleri normaldi. Koranal ve aksiyel planlarda elde edilen paranazal bilgisayarlı tomografi (BT) tetkikinde sol nazal kavite posteriorunda bu bölgeyi ve koana sol yarısını tama yakın oblitere ederek nazofarenkse uzanan, çevre kemik dokularda destrüksiyona yol açmamış yaklaşık $3 \times 2.5 \mathrm{~cm}$ boyutlarında yumuşak doku kitlesi saptandı. Pre-postkontrast aksiyel, koronal SE T1A,T2A ve sagittal postkontrast SE T1A manyetik rezonans görüntülemede (MRG) sol nazal kavitede egzofitik olarak 
hava boşluğuna doğru büyüme gösteren, koanaya doğru ilerlemiş, alt ve orta konkalar ile arasındaki planları sililinmiş $3 \times 2.5 \mathrm{~cm}$ boyutlarında kitle saptandı. Kitle heterojen iç yapıda T2A serilerde heterojen, orta derecede hiperintens, kontrastsı T1A serilerde hipointens, postkontrast serilerde belirgin heterojen opaklaşma gösteren düzgün lobüle kontürlü idi ve çevresindeki yumuşak doku planlarında patolojik sinyal değişiklikleri eşlik etmemekte idi (Şekil-1a).
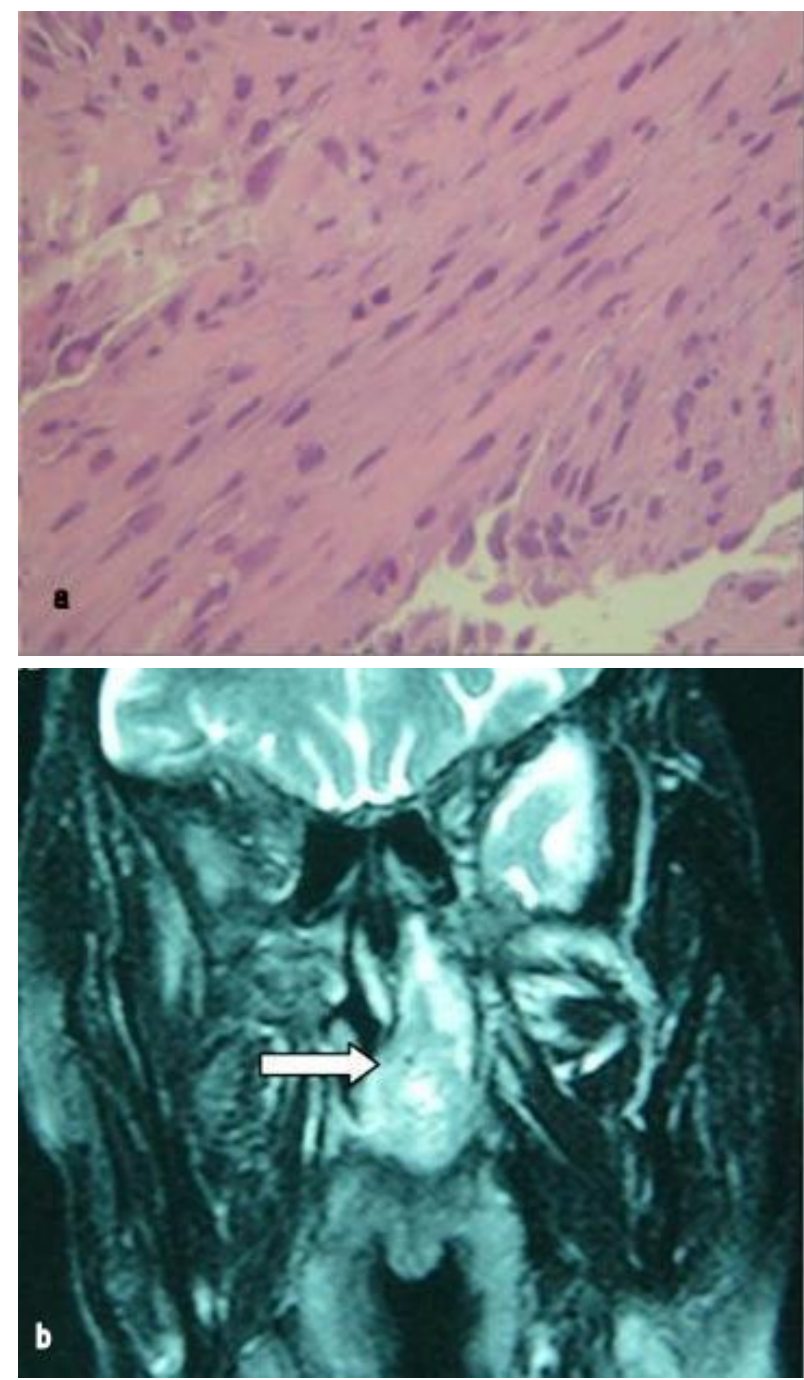

Şekil-1. a. Olgunun histolojik incelemesinde nükleer atipi gösteren, hiperkromatik ve kaba kromatinli künt çekir-dekler olan, eozinofilik stoplazmalı, çapraz kemerler halinde fasiküller oluşturmuş uzun, fuziform hücreler ve çok sayıda mitotik figür izlenmekte (HE,x100). b. Koronal postkontrast T2 ağırlıklı MRG serisinde nazal kavite posteriorundan geçen kesitte belirgin inhomojen kontrast tutulumu gösteren, egzofitik olarak hava boşluğuna doğru büyüme gösteren, lobüle kontürlü kitle görülmekte (beyaz ok).

Histolojik inceleme için kitleden alınan biyopsinin sonucunun LMS olarak bildirilmesi üzerine önce olası tutulum ve metastaz bölgelerini değerlendirmek amacıyla yapılan PET/BT'de nazal kavite haricindeki bölgelerde tutulum saptanmaması üzerine küratif cerrahi rezeksiyon planlandı. Genel anestezi altında transnazal endoskopik yaklaşımla yapılan cerrahide sol alt konkanın posterioru ve maksilla medialinden kaynaklanarak nazal kavite ve oradan nazofarenkse ekzofitik uzanım göstermiş yaklaşık $5 \times 3 \mathrm{~cm}$ boyutlarındaki kitle, peroperatif cerrahi sınırlardan donuk kesit patolojik inceleme yapılarak yaklaşık $1.5 \mathrm{~cm}$ güvenli cerrahi sınırlar sağlanarak rezeke edildi (sınırlı medial maksillektomi). Cerrahi spesimenin immünohistokimyasal ve histolojik incelemesi LMS ile uyumlu (bol eozinofilik stoplazmalı fuziform hücre fasikülleri, düz kas aktini ve desmin ile diffüz pozitif, S-100 ile negatif boyanma patterni, Ki 67 proliferatif indeksi $32 \%$ ) ve cerrahi sınırlar tümör açısından negatif olarak saptandı (Şekil-b). Total tümör eksizyonu ile tanının kesinleşmesini takiben, günlük doz 2 Gray olacak şekilde $35 \mathrm{kez}$, toplam 70 Gray RT uygulandı. Tedaviyi takip eden 38 aylık süreç içerisindeki izleminde hastada lokal rekürrense ve uzak metastaza ait bulguya rastlanmadı.

\section{Tartışma}

Baş ve boyun bölgesinin yumuşak doku sarkomları bu bölgenin nadir tümörlerindendir. Fusconi ve ark 2002 yılında yaptıkları derlemede literatürde şimdiye kadar 41 sinonazal LMS olgusu bulunduğunu belirtmişlerdir (4). Huang ve Antonescu'nun 2003 yılında yayımlanan derlemelerinde sinonazal LMS'un saptanma yaşının ortalama 50 olduğu ve $1 / 1.5$ oranıyla kadınlarda biraz daha sık görüldüğü, en sık başvuru şikayetlerinin burun tıkanıklığı ve burun kanaması olduğu belirtilmiştir. İlginç olarak LMS'da, leiyomiyomdan farklı olarak ağrı ve hassasiyet görülmez. Sunulan olgu da bu epidemiyolojik özelliklerle uyumlu olarak 57 yaşında, kadın cinsiyetteydi ve en sık başvuru şikayetlerinden olan tek taraflı burun tıkanıklığı ve kanaması ile başvurmuştu ve ağrısı yoktu. Sinonazal bölge LMS'larının tanı sırasındaki ortalama büyüklüğü 3 cm'dir ve izole nazal kavite tutulumu, paranazal ve kombine sinonazal tutuluma göre daha sıktır (5). Hastamızda da kitle, başvuru sırasında yaklaşık $4 \mathrm{~cm}$ idi ve paranazal tutulum saptanmamıştı. LMS'lar BT'de genelde nekrotik veya kistik alanlar içerebilen, kalsifikasyon göstermeyen, kemik destrüksiyonunun sık olduğu masif kitle olarak görülürler. MRG'de ise heterojen, T2 ağırlıklı imajlarda orta-yüksek sinyal zenginliğindedir $(1,5)$. Sunulan olgunun BT tetkikinde de kitlede kalsifikasyon yoktu fakat sık görülen kemik invazyonu özelliğini göstermemekte, MRG'de ise literatürle uyumlu olan heterojen, postkontrast yüksek sinyal özelliklerinde idi.

Lokal agresif seyretmeye meyilli olan LMS'larının prognozu hakkında yeterince veri yoktur fakat kadın genital sistemi ve gastrointestinal bölgeden kaynaklananlara göre sinonazal bölgenin LMS'larının daha selim davranış gösterdikleri söylenebilir. LMS'larda lokal rekürrens $34 \%$, bölgesel metastaz $15 \%$, uzak metastaz 
$35 \%$ ve 5 yıllık sağkalım $55-73 \%$ oranlarında bildirilmiştir (6). Hastamızda tanı sırasında boyun ve uzak metastaz ile uyumlu bulgu yoktu ve tedavi sonrası 3 yılı aşkın sürede lokal ve/veya uzak metastaz saptanmamıştır. Prognostik faktörler açısından veriler yeterli olmamakla birlikte $3 \mathrm{~cm}$ 'den büyük ve histopatolojik incelemede 5 büyütmelik alanda birden fazla mitozun olması kötü prognozla ilişkilendirilebilir. Orbita, pterigomaksiller fossa ve kafa tabanı tutulumu riski artacağından paranazal tutulum daha kötü prognoz getirir (7).

LMS tedavisinin temelini güvenli cerrahi rezeksiyon oluşturur. Tümör boyutu $4 \mathrm{~cm}$ 'den büyük ise cerrahi sonrası RT önerilmektedir (8). Sinonazal bölge LMS'larının cerrahisi tedavisindeki başarı tümörün boyutu ve nazal kavite kaynaklı olması ile indirekt olarak ilişkilendirilmiştir. Eğer cerrahi tek tedavi yöntemi olacaksa rezeksiyon sınırları tümörden en az $1 \mathrm{~cm}$ uzaklıkta olmalıdır $(7,8)$. Sinonazal yerleşimli tümörlerde düşük rejyonel lenf nodu metastaz oranları nedeniyle elektif boyun diseksiyonuna gerek yoktur $(8,9)$ LMS tedavisinde moleküler hedefli KT yapılmaya başlanmıştır fakat bu tedavi baş-boyun bölgesini içermemektedir çünkü bu bölge LMS'larının gen paternleri halen bilinmemektedir (6). Sunulan olguda öncelikle güvenli salim cerrahi sınırlar elde edilerek endoskopik rezeksiyon uygulanmış ve tümör çapı $4 \mathrm{~cm}$ 'den fazla olduğu için de postoperatif RT uygulanmıştır. Bölgesel lenf nodu metastazı saptanmadığından boyun diseksiyonu uygulanmamış ve literatürde henüz etkinliği netleşmediğinden KT uygulanmamıştır. Hastamızın RT bitiminden sonraki 38 aylık düzenli kontrollerinde henüz lokal nüks ve uzak metastaz saptanmamış olması bu tedavinin etkili olduğunu düşündürmektedir.

Sonuç olarak, baş ve boyun bölgesinin nadir malignitelerinden olan bu LMS olgusu bize özellikle bu tümörün tedavisinde cerrahinin temel rol oynadığını ve cerrahi sonrası RT uygulamasının da tedavi etkinliğini artırabileceğini desteklemesi yönünde önemli bir örnek teşkil edebilir.

\section{Kaynaklar}

1. Kuruvilla A, Wenig BM, Humphrey DM, Heffner DK. Leiomyosarcoma of the sinonasal tract. A clinicopathologic study of nine cases. Arch Otolaryngol Head Neck Surg 1990;116(11):1278-86.

2. Ulrich CT, Feiz-Erfan I, Spetzler RF et al. Sinonasal leiomyosarcoma: Review of literature and case report. The Laryngoscope 2005;115(12): 2242-48.

3. Cheng EY, Dusenbery KE, Winters MR, Thompson RC. Soft tissue sarcomas: Preoperative versus postoperative radiotherapy. J Surg Oncol 1996;61(2):90-9.

4. Fusconi M, Magliulo G, Della Rocca C, Marcotullio D, Suriano M, de Vincentiis M. Leiomyosarcoma of the sinonasal Tract: A case report and literature review. Am J Otolaryngol 2002;23(2):108-11.

5. Huang HY, Antonescu CR. Sinonasal smooth muscle cell tumors: A clinicopathologic and immunohistochemical analysis of 12 cases with, emphasis on the low-grade end of the spectrum. Arch Pathol Lab Med. 2003;127(3):297-304.

6. Jagveer $\mathrm{Y}$, Jaimanti, Mahendra C, and Rahul M. Head and Neck Leiomyosarcoma. Indian J Otolaryngol Head Neck Surg.2013;65(Suppl1):1-5.

7. Akcam T, Oysul K, Birkent H, Gerek M, Yetiser S. Leiomyosarcoma of head and neck: Report of two cases and review of literature. Auris Nasus Larynx. 2005;32(2):209-12.

8. Eilber FR, Eckardt J. Surgical management of soft tissue sarcomas. Semin Oncol 1997;24(5): 526-33.

9. Pisters PW, Harrison LB, Leung DH, Woodruff JM, Casper ES, Brennan MF. Long term results of a prospective randomized trial of adjuvant brachytherapy in soft tissue sarcoma. J Clin Oncol 1996;14(3): 859-68. 